\title{
Versatility of a New Thermoplastic Material for Use in Prosthodontics: A Potential Material for a Promising Future
}

\author{
Manoharan $\mathrm{PS}^{1} \odot$, Pradeep Raja $\mathrm{BT}^{2} \odot$, Saikiran Koppolu ${ }^{3}$
}

\begin{abstract}
Prosthodontics more than any other dental specialty has shown the capability of evolution in response to changing needs and will probably continue to change. Emerging concepts, materials, and technologies impact the education, research, and practice of prosthodontics. One such evolution is the introduction of a thermoplastic impression material used in the fabrication of CAD-CAM dentures. Unless we are abreast of recent trends and developments taking place in various fields appropriate to the specialty, one will get isolated from the scientific arena with the risk of losing the perspective. So, the aim of this short communication is to give a glimpse of the new impression material, its uses, and scope of research.
\end{abstract}

Keywords: Baltic denture, CAD-CAM dentures, Impression material, Interocclusal record material.

Journal of Scientific Dentistry (2021): 10.5005/jp-journals-10083-1002

A constant quest for the search of new materials and its knowledge and practice in the field of prosthodontics has played a vital role in enhancing the quality of replacements in terms of its performance. The evolution of impression materials over the period of time has aimed to improve in terms of detail reproduction, tear strength, dimensional accuracy, comfort to the patient, easy manipulation, and compressive resistance. Many impression materials in the past have been modified to perform as an interocclusal record or a bite registration material. ${ }^{1,2}$

In the past decade, a new thermoplastic impression material has evolved for its exclusive use in the fabrication of CAD-CAM dentures [BD Impress ${ }^{\oplus}$ ]. In complete dentures, traditionally primary and secondary impressions are made for accuracy and detail reproduction. The Baltic system of CAD-CAM dentures uses BD Impress as a single-stage impression material along with other denture procedures like jaw relation, doting on the advantageous properties of the material..$^{3,4}$ In the instruction manual of this material, its use has been advised for border molding and for making interocclusal records. ${ }^{5}$

BD Impress ${ }^{\oplus}$ is a thermoplastic resin, which is described as a translucent material that can be manipulated by softening in a water bath or by direct flame. It is dispensed in the form of white hard resin balls of 3-4 $\mathrm{mm}$ diameter. It was also claimed by the manufacturer that the material can be molded to a stick form using a water bath and used for border molding. It is odorless and can be reused for the same patient multiple times without change in property. It is claimed to be precise and dimensionally stable producing good surface quality, superior strength, and compression resistance. Ease and quickness in manipulation have made this material very user-friendly. ${ }^{5}$

The applications of this material, as a border molding material and an interocclusal record material, have been tested at the institute for its accuracy and compressive resistance. It was found to be extremely superior in terms of detail reproduction, dimensional accuracy [reproducible up to 25 microns], and
${ }^{1-3}$ Department of Prosthodontics, Crown and Bridge, Indira Gandhi Institute of Dental Sciences, Sri Balaji Vidyapeeth, Puducherry, India

Corresponding Author: Manoharan PS, Department of Prosthodontics, Crown and Bridge, Indira Gandhi Institute of Dental Sciences, Sri Balaji Vidyapeeth, Puducherry, India, Phone: +91 9865019673, e-mail:manodent_2000@yahoo.com

How to cite this article: Manoharan PS, Raja BTP, Koppolu S. Versatility of a New Thermoplastic Material for Use in Prosthodontics: A Potential Material for a Promising Future. J Sci Den 2021;11(2):70-71.

Source of support: Nil

Conflict of interest: None
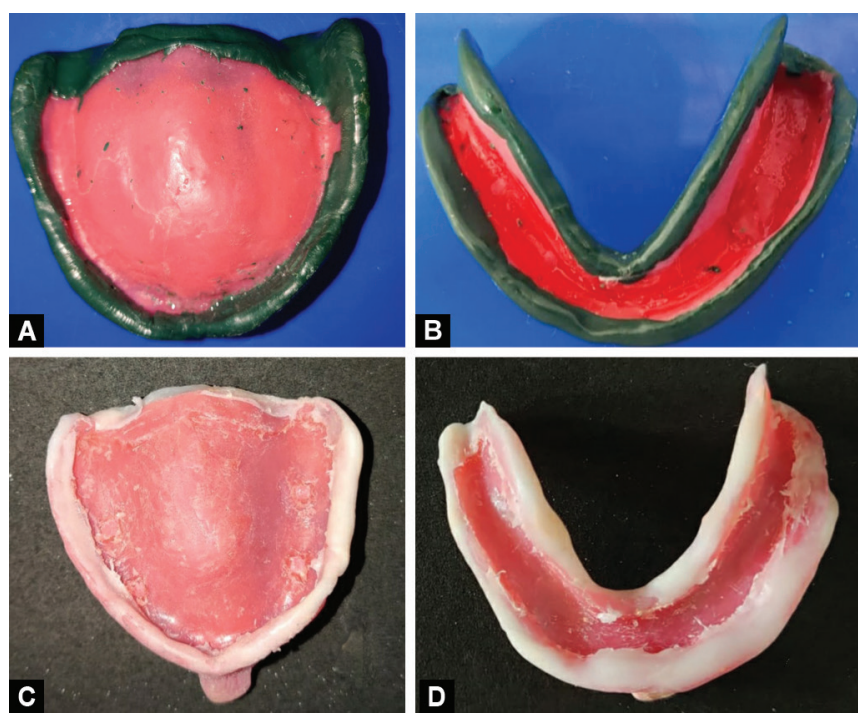

Figs $1 A$ to $D$ : (A and B) Border molding carried out with the traditional method using greenstick; ( $C$ and $D)$ Border molding carried out with thermoplastic impression material (BD Impress)

() The Author(s). 2021 Open Access This article is distributed under the terms of the Creative Commons Attribution 4.0International License (https://creativecommons. org/licenses/by-nc/4.0/), which permits unrestricted use, distribution, and non-commercial reproduction in any medium, provided you give appropriate credit to the original author(s) and the source, provide a link to the Creative Commons license, and indicate if changes were made. The Creative Commons Public Domain Dedication waiver (http://creativecommons.org/publicdomain/zero/1.0/) applies to the data made available in this article, unless otherwise stated. 

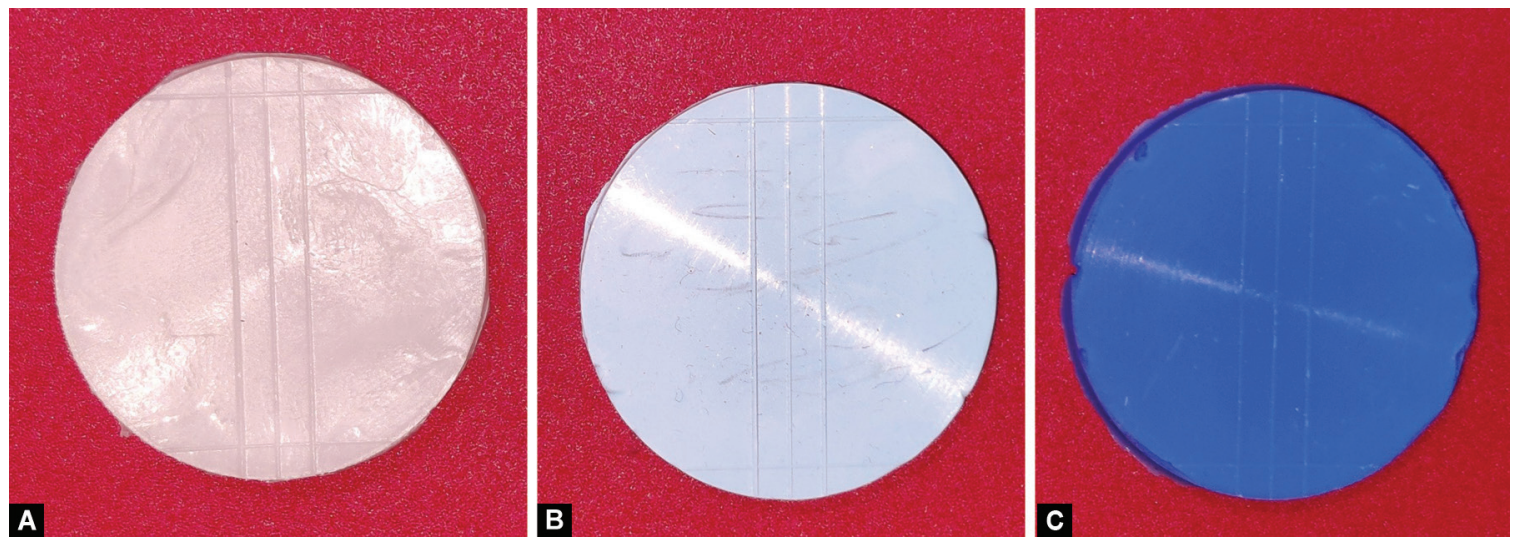

Figs $2 \mathrm{~A}$ to C: A study has been conducted in the institute for evaluating the compressive resistance, detailed reproduction, and dimensional accuracy of three different interocclusal record materials. With BD Impress ${ }^{\circledR}$ superior in terms of detail reproduction, dimensional accuracy [reproducible up to 25 microns], and compression resistance. (A) BD Impress ${ }^{\circledast}$; (B) Ivoclar Virtual CAD-Bite; (C) DMG Luxabite

compression resistance (Figs 1 and 2). The initial experience with the clinicians in handling the material was also found to be better than conventional materials like greenstick or putty elastomers in border molding. The patient-perceived comfort was also found to be better when compared with other materials during manipulation of tissues in the border-molding procedure.

It is henceforth appealed to the scientific fraternity to explore the possibilities for the use of this material in prosthodontics. More research is also encouraged to prove the validity of this material in its clinical usage.

\section{OrCID}

Manoharan PS ๑ https://orcid.org/0000-0002-3048-5155 Pradeep Raja BT @ https://orcid.org/0000-0002-1201-4392

\section{References}

1. Megremis S, Tiba A, Vogt K. An evaluation of eight elastomeric occlusal registration materials. J Am Dent Assoc 2012;143(12):13581360. DOI: 10.14219/jada.archive.2012.0101.

2. Wieckiewicz M, Grychowska N, Zietek M, Wieckiewicz W. Evaluation of the elastic properties of thirteen silicone interocclusal recording materials. BioMed Res Int 2016;2016:1-8. DOI: 10.1155/2016/7456046.

3. Peroz S, Peroz I, Beuer F, Sterzenbach G, von Stein-Lausnitz M. Digital versus conventional complete dentures: a randomized, controlled, blinded study. J Prosthet Dent 2021;S0022-3913(21)00073-1. DOI: 10.1016/j.prosdent.2021.02.004.

4. John A, Abraham G, Alias A. Two-visit CAD/CAM milled dentures in the rehabilitation of edentulous arches: a case series. J Indian Prosthodontic Soc 2019;19(1):88. DOI: 10.4103/jips.jips_252_18.

5. BD Impress ${ }^{\oplus}$-Merz Dental GmbH [Internet]. Merz-dental.de. 2021. Available from: https://www.merz-dental.de/en/dental-labs/ equipment/bd-impressr. 